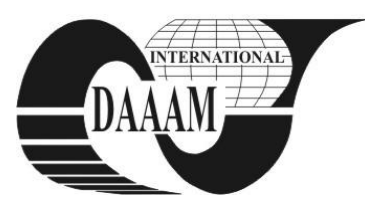

\title{
THE USE OF MODERN TEACHING AIDS IN BIOLOGY CLASSES IN PRIMARY SCHOOLS OF POZEGA-SLAVONIA COUNTY
}

\author{
ZIMA, D[inko]
}

\begin{abstract}
New technologies in most school subjects have become an integral part of school teaching and learning. The survey analysis shows that in primary schools of PozegaSlavonia County, Croatia, biology teachers want to use modern aids, believe that they have an opportunity for it, that it makes teaching more interesting for pupils and enables them to learn teaching material more efficiently. In spite of that they do not use these aids in every class but mostly once a month. The introduction of modern technologies in teaching cannot entirely replace traditional forms of biology teaching, but it can reinforce them and thus make them easier
\end{abstract}

Key words: school classes, modern technologies, a computer, biology

\section{INTRODUCTION}

New tecnologies have introduced the human race into the era of universal communication: by cutting distances they form tomorrow's societies which, due to these technologies, will not have anything in common with any model from the past (Delors et al., 1998).

In today's age, when pupils are oriented towards the use of computers in their free time (games, the Internet), it is very important to use computers in teaching. In the $21^{\text {st }}$ century technology will take big steps ahead and crucially change the way people work, communicate and learn. Information technology will have a dramatical influence, especially on medicine and education, and the differences between the rich and poor will diminish (Stevanovic, 2000). While teaching, teachers have to encourage their students to reach their maximum as much as possible and, by taking into account the things mentioned above, it is clear that young generations will achieve it easier by the use of modern technologies in class.

\section{THEORETICAL OVERVIEW}

Teaching styles can be classified into four groups according to the amount of using information and communications (IC)

technology:

a) classical lessons where lecturing is dominant and almost completely held in a classroom with a minimal use of IC technology

b) lessons supported by IC technology, where technology is used to improve lessons but to a certain point (presentations, use of CD-ROMs, installing web-centres for subjects, and similar)

c) mixed lessons are a combination of classical classroom teaching and lessons supported by IC technology

d) on-line lessons where teaching and learning is performed with the use of IC technology exclusively, in the way that students receive school materials via the Internet or videoconferencing (Divjak et al., 2008).

To use computers for a teacher means: to make week's, month's and year's plans and programs; to create and make preparations for school lessons and days; to access an e-matrix; to develop a timetable of excursions and field-classes during a school year; to keep a record of personal professional training; to make lists with students' names, lists of students and students' databases; to create class and/or school newspapers; to store students' individual or group essays; to communicate with colleagues and experts by e-mail etc.

New technologies in most school subjects have become an integral part of school teaching and learning. They can be used in planning, performing and assessing of teaching processes, and with regard to this almost all new textbooks include a CD with presentations, while teacher's books also contain prepared materials for lessons. It is a fact that the use of new technologies in teaching depends on a school subject, a teacher (tendencies towards new technologies, age, etc.) and students.

\subsection{Work forms}

When we use the most modern media - a computer, we can choose from the following work forms: work.

a) individual work; b) pair work; c) group work; d) team

Individual work can be performed if every pupil has a computer. Pupils get instructions for work and dedicate themselves to independent learning, they set the speed of work, they research and reach results.

Pair work has more advantages and one is that a pupil who has problems in acquiring educational tasks gets some information from a pupil who is more advanced and who works with them in a group. While doing so, we need to take care that the advanced pupil does not neglect other pupils, but at the same time that the weaker pupils do not have a passive role or are not preoccupied with other activities. If pupils work in pairs, it is also possible to allocate tasks, so that one pupil does one part and the other the rest. When giving homework to find some information on the Internet, we can divide pupils into pairs, since not every of them may have access to the Internet.

Group work is not entirely acceptable when working with computers because of technical reasons. All students cannot be busy at the same time, but it is possible to allocate tasks to pupils and to divide the group work into stages: a) receiving working tasks, b) independent research-work of a group, c) presenting, generalizing and recording final results.

Team work is applied in more types of computer-supplied classrooms where a pupil can communicate with the teacher and other pupils. Today it is also possible at home by using access to the global network, by entering certain "virtual rooms" where communication is kept among the members.

It depends on a teacher which method and work form to choose, but it is important to keep in mind that a wrong method or work form can lead to not entirely acquired educational and functional tasks, while the more appropriate method and form would have much better effects, even if it requires that we do not use a computer as the media.

\subsection{The modified role of a teacher}

The use of modern technologies in teaching means that a teacher should adapt to a new role. While doing so, the teacher 
must improve their knowledge and skills, suggest potential sources of knowledge to the pupils as well as the ways to reach them, formulate and determine discussion flows about collected terms and recommend additional materials for learning and studying. All the facts mentioned clearly indicate that the role of the teacher, while using modern technologies, is not reduced but altered. The teacher is not merely a lecturer, but also a motivator and a proposer, a track-setter, and a reviser of available pieces of information. Application of digital media increases communication between teachers and pupils, in some cases replaced teachers, and can motivate even those pupils who have got all the other method proved less successful (Nadrljanski, et al., 2007).

\subsection{Situation in Croatia}

A personal computer connected to the Internet is available to the growing number of families in Croatia. A similar trend of supplying schools with modern information and communication technologies also takes place, in which process all primary and secondary schools in Croatia have gained the Internet access through an ISDN connection. Each school has at least one computer with the Internet access, available to pupils and teachers. Our teachers' computer literacy is poor and considerably falls behind the pupils'. It causes a relatively low rate of usage of the already minimal resources that are assigned and available through the process of computerization and internetization of the Croatian educational system.

\subsection{The use of new technologies in biology teaching}

In biology, the first priority is to develop learners' observing abilities, but even in that process contemporary teaching aids and technologies can have an important role. It is especially related to different animations, audio and video recordings of phenomena that need to be observed during longer periods of time, displaying of cell structures that cannot be seen by a light microscope, teaching with PowerPoint presentations and similar. The use of computers during the revision of teaching content should not be neglected.

\section{RESEARCH METHODS}

The aim of this work is to determine the level of use of modern technologies in biology teaching by the teachers of Pozega-Slavonia County, Croatia. A survey has been conducted on the sample of 12 teachers coming from 12 different primary schools ( $80 \%$ of total number).

\section{RESULTS}

The survey analysis shows that all the teachers want to introduce modern teaching aids; they all believe that those aids provide better acquiring of the curriculum and that biology teaching is more interesting to the pupils if contemporary teaching aids are used. Out of the total number of surveyed teachers, $58.3 \%$ of them are under the age of 40 , while $41.7 \%$ are over the age of 50.10 of the surveyed teachers use modern aids in teaching $(83.3 \%)$. The teachers mostly project the entire lecture or its part through an LCD projector $(69.3 \%)$. Those who use modern aids use them mostly once per week $(41.7 \%)$ or once per month (Fig. 1). Regarding teachers who do not use modern teaching aids, some of them consider themselves old to use those aids and find them complicated to connect, some schools do not have modern aids, and some responded that the school does not have a specialized biology classroom, indicating that as a restrictive factor. It is slightly worrying that out of all teaching aids the largest number (38.5\%) of teachers still uses a blackboard and chalk (Fig. 2).

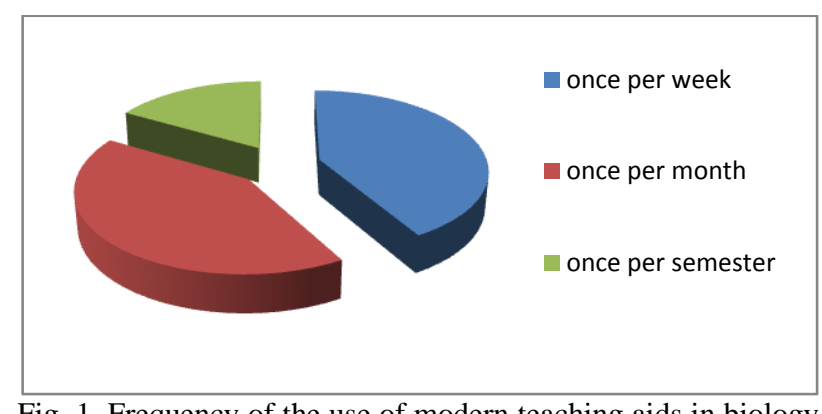

Fig. 1. Frequency of the use of modern teaching aids in biology classes

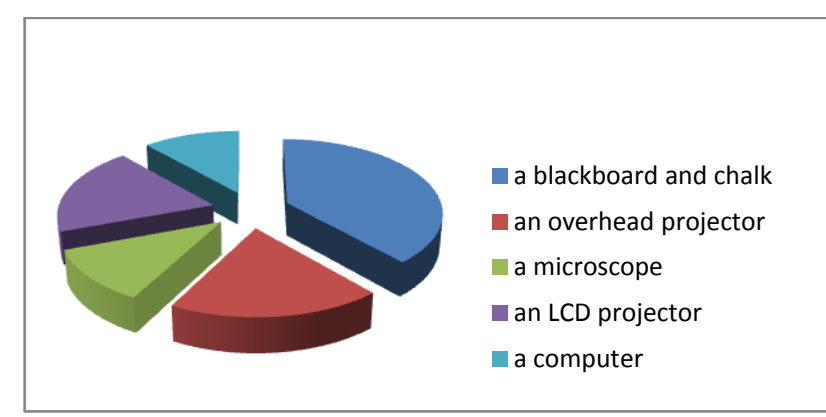

Fig. 2. The most commonly used teaching aids in biology classes

\section{CONCLUSION}

New information technologies, especially computers, are becoming an increasingly important didactic tool and medium for information transfer between teachers and pupils. In primary schools of Pozega-Slavonia County biology teachers want to use modern aids, believe that they have an opportunity for it, that it makes teaching more interesting for pupils and enables them to learn teaching material more efficiently. In spite of that they do not use these aids in every class but mostly once a month. The restrictive factors for the use of modern aids in biology teaching are: the lack of specialized classrooms, unequipped schools and uneducated teachers. New technologies have an increasing role in teaching, but they are still not substantially represented. In the future biology teaching, more and more teachers will exploit benefits of these possibilities, but they will not be able to completely substitute the process of observation of certain phenomena in nature. Rather, they will supplement that process and make it more available and more interesting. All that leads to the conclusion that the introduction of modern technologies in teaching cannot entirely replace traditional forms of biology teaching, but it can reinforce them and thus make them easier.

\section{REFERENCES}

Delors, J., et al. (1998). Learning treasure inside us. Educa, Zagreb

Divjak, B., et al. (2008). Outcomes of learning in higher education. Faculty of organization and informatics, Varazdin

Ljubic Klemse, N. (2011). Technology application in teaching and expectations of teachers. Available from http://www.zbornica.com- Accessed: 2011/07/21

Nadrljanski, Dj., Nadrljanski, M., Tomasevic, M. (2007). Digital media in education system-review of international practice. Available from http://infoz.ffzg.hrINFuture/2007. Accessed: 2011/08/23

Stevanovic, M. (2000). Models of creative teaching. R\&S, Tuzla 